the Royal Institute of Chemistry, the Society of Chemical Industry and the Institute of Metals. Sir George Beilby was president of each of these three bodies, and they jointly sponsored the appeal for subscriptions whereby the Fund was raised as a memorial to him after his death in 1925. The Beilby Medal and Prize, which consists of a gold medal and a substantial sum of money, is specified as being "For Advancement in Science and Practice". Such an award is now being offered annually. The awards are made to British scientists in recognition of independent original work of exceptional merit, carried out continuously over a period of years and involving the development and application of scientific principles in any field related to the special interests of Sir George Beilby, namely chemical engineering, fuel technology or metallurgy, in their modern interpretations. The awards are intended as an encouragement to younger men and women (preferably under the age of 40 ) who have done distinguished work of practical significance in any of these fields. The award for 1966 is shortly to come up for consideration. Outstanding work of the nature indicated may be brought to the notice of the Administrators, either by persons who desire to recommend the candidate or by the candidate himself, not later than December 31, 1965, by letter addressed to the Convener of the Adminis. trators, Sir George Beilby Memorial Fund, the Royal Institute of Chemistry, 30 Russell Square, London, W.C.1.

\section{Meldola Medal, 1965}

The next award of the Meldola Medal, the gift of the Society of Maccabaeans, will be made early in 1966 to the chemist who, being a British subject and less than 30 years of age on December 31, 1965, shows the most promise as indicated by his or her published chemical work brought to the notice of the Council of the Royal Institute of Chemistry before December 31, 1965. Further information can be obtained from the President, the Royal Institute of Chemistry, 30 Russell Square, London, W.C.1, the envelope being marked "Meldola Medal".

\section{Announcements}

DR. M. C. WILliams has been appointed to the directorship of the Virus Research Institute at Entebbe, and has already taken over his duties.

THE 1965 congress of the International Federation for Documentation will be held in Washington during October 10-16. Further information can be obtained from the
Secretariat of the Congress, 9650 Wisconsin Avenue, Washington, D.C.

A symposium on "Computers in Medicine" will be held in Queen's University, Kingston, Ontario, during October 7-8. Further information can be obtained from the Director of Continuing Education, Faculty of Medicine, Queen's University, Kingston, Ontario.

THE national conference of the Institute of Personnel Management on "Making the Most of Manpower" will be held at Harrogate during October 7-9. Further information can be obtained from the Institute of Personnel Management, 80 Fetter Lane, London, E.C.4.

A Meetrng on "Oxidation of Metals", organized by the Société d'Etudes, de Recherches et d'Applications pour l'Industrie, will be held in Brussels during October 6-8. Further information can be obtained from Mr. C. Sonnen, c/o S.E.R.A.I., 1091 Chaussée d'Alsemberg, Brussels 18.

A symposium on "Industrial Organic Analysis", sponsored by the Analytical Chemistry Division of the Chemical Institute of Canada, will be held at Sarnia during October 4-6. Further information can be obtained from R. M. Small, Research Department, Polymer Corporation, Ltd., Sarnia, Ontario.

AN informal meeting of the Physical Biochemistry Group of the British Biophysical Society on "Light Scattering" will be held at the School of Pharmacy, University of London, on October 4. Further information can be obtained from Prof. L. Saunders, School of Pharmacy, Brunswick Square, London, W.C.1.

A CONFERENCE on "Mathematics for Engineers", sponsored jointly by the Engineering Institutions Joint Council, the Institute of Mathematics and its Applications and the Joint Mathematical Council of the United Kingdom, will be held at Queen Mary College, London, during September 30-October 1. Further information can be obtained from the Registrar, Institute of Mathematics and its Applications, c/o Imperial College of Science and Technology, London, S.W.7.

Corrigendum. Prof. A. H. Glässer has written to the Editor stating that the chemical compound described in his joint communication with Dr. C. Beretta and Dr. R. Ferrini, which appeared on p. 421 of the July 24, 1965, issue of Nature, was in fact "1,6-Dimethyl-8 $\beta$-carbobenzyloxyaminomethyl-10 $\alpha$-ergoline" and not "1-Methyl$8 \beta$-carbobenzyloxyaminomethyl-10 $\alpha$-ergoline".

\title{
THE NIGHT SKY IN OCTOBER
}

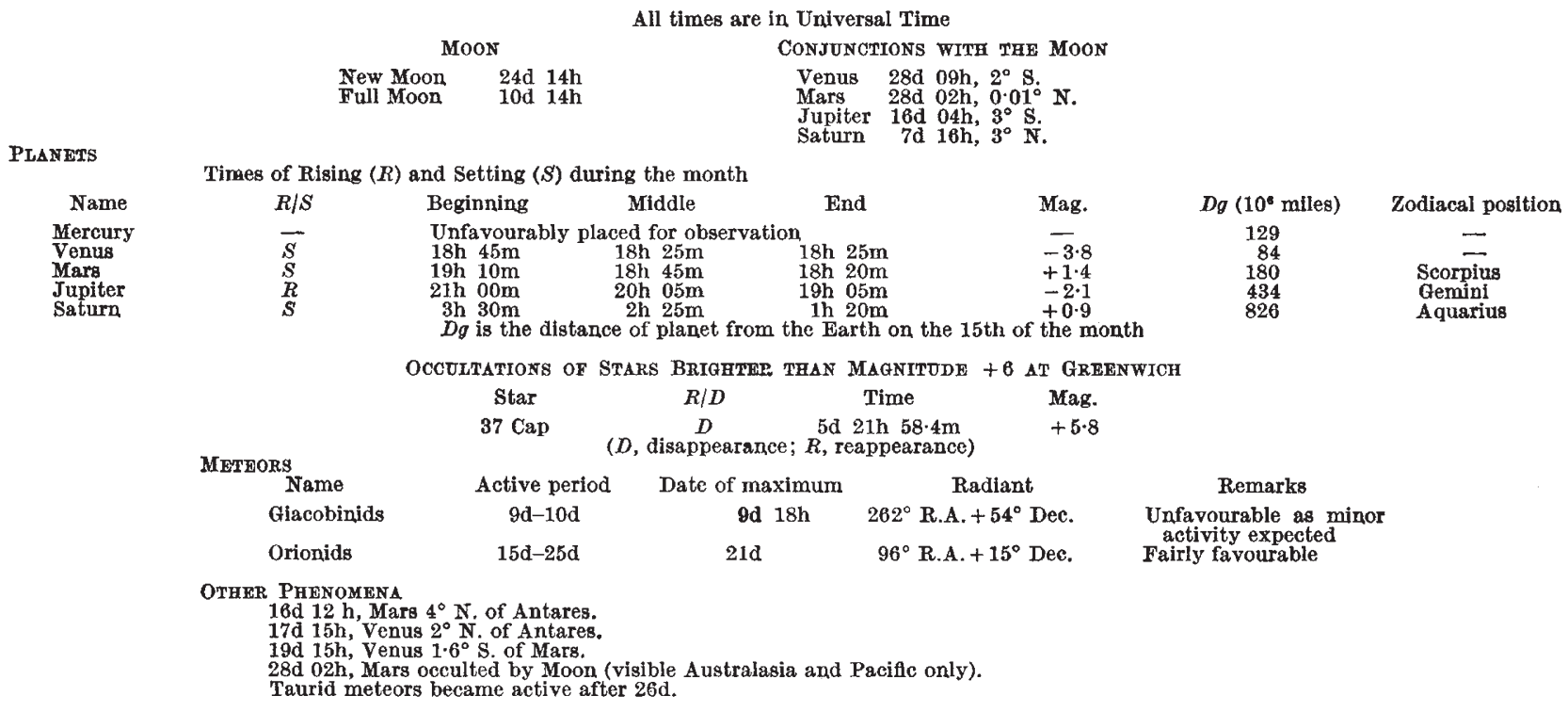

